Hasil Penelitian

\title{
PENERAPAN PENDIDIKAN KARAKTER MELALUI PROgRAM GERAKAN KEPANDUAN HIzBUL WATHAN PADA sEKOLAH DASAR MUHAMMADIYAH UI PALEMBANG
}

\author{
OMusni Ependi \\ Program Pascasarjana \\ Universitas Islam Negeri Raden Fatah Palembang \\ E-mail:musni_uin@radenfatah.ac.id
}

\begin{abstract}
Each individual is expected to have a character, because someday when an individual gathered in the community, then able to be a good man and who can be proud of. And without realizing each individual has a noble character, starting from leading himself, lead the family, or lead an organization both in the school environment, community environment, and work environment. To reveal the second side, this study formulates the following issues: (1) How to Implement Character Education Through Hizbul wathan Scouting Movement at Primary School Muhammadiyah 6 Palembang? (2) What are the factors that hamper the Implementation of Character Education through Hizbul wathan Scouting Movement at Muhammadiyah Primary School 6 Palembang? To answer that question, this research was designed with the design and implemented in Elementary School Muhammadiyah 6 Palembang. This research uses qualitative field approach that is descriptive qualitative, data collection technique using interview (wawncara) and documentation. Analytical techniques through the data reduction phase, data presentation, and conclusion. The results of the field research have been found (a) Hizbul Wathan's activity at Elementary School Muhammadiyah 6 Palembang has been held since the school was established due to the instruction from Muhammadiyah Central Executive that all schools under Muhammadiyah must perform Hizbul Wathan activities. (B) the implementation of Hizbul Wathan's activities at Muhammadiyah Primary School 6 Palembang is still far from what is expected due to the many obstacles and inhibiting factors (c) in this case with the existence of various obstacles and inhibiting factors of activity hence the purpose of Hizbul Wathan activity to instill the values Leadership is also not running smoothly, but until now the teachers have tried to hold activities in accordance with the planting values of leadership
\end{abstract}

as well as camping activities. To give contribution of school thinking to keep developing and improving its competence in character education implementation through hizbul wathan scouting activity, here arises concept and strategy of constructor in terms of achievement of character education result that effectively and efficient.

Keywords: Education, Character, Hizbul Wathan

\begin{abstract}
Abstrak
Setiap diri individu diharapkan mempunyai karakter, karena kelak suatu saat apabila seorang individu berkumpul dimasyarakat, maka mampu menjadi insan yang baik dan yang dapat dibanggakan. Dan tanpa disadari setiap diri individu telah memiliki akhlak mulia, dimulai dari memimpin dirinya sendiri, memimpin keluarga, atau memimpin suatu organisasi baik di lingkungan sekolah, lingkungan masyarakat, maupun dilingkungan pekerjaan. Untuk mengungkapkan sisi kedua tersebut penelitian ini merumuskan masalah sebagai berikut: (1) Bagaimana Penerapan Pendidikan Karakter Melalui Gerakan Kepanduan Hizbul wathan di Sekolah Dasar Muhammadiyah 6 Palembang? (2) Apakah faktor-faktor yang menghambat Penerapan Pendidikan Karakter Melalui Gerakan Kepanduan Hizbul wathan di Sekolah Dasar Muhammadiyah 6 Palembang? Untuk menjawab pertanyaan tersebut, penelitian ini dirancang dengan rancangan serta dilaksanakan di Sekolah Dasar Muhammadiyah 6 Palembang. Penelitian ini menggunakan pendekatan kualitatif lapangan yang bersifat deskriptif kualitatif, teknik pengumpulan datanya menggunakan interview (wawncara) dan dokumentasi. Teknik analisisnya melalui tahapan reduksi data, penyajian data, serta penarikan kesimpulan. Hasil penelitian dilapangan telah ditemukan (a) kegiatan Hizbul Wathan di Sekolah Dasar Muhammadiyah 6 Palembang telah diadakan sejak sekolah tersebut berdiri dikarenakan perintah dari Pimpinan Pusat Muhammadiyah
\end{abstract}




\section{Hasil Penclitian}

bahwasannya seluruh sekolah yang dibawah naungan Muhammadiyah wajib mengadakan kegiatan Hizbul Wathan. (b) pelaksanaan kegiatan Hizbul Wathan di Sekolah Dasar Muhammadiyah 6 Palembang masih jauh dengan apa yang diharapkan kerana banyaknya kendala dan faktor penghambat(c) dalam hal ini dengan adanya berbagai kendala dan faktor penghambat kegiatan maka tujuan dari kegiatan Hizbul Wathan untuk menanamkan nilai-nilai kepemimpinan juga kurang berjalan dengan lancar, tetapi sampai saat ini pihak guru sudah berusaha mengadakan kegiatan yang sesuai dengan penanaman nilai-nilai kepemimpinan seperti halnya kegiatan perkemahan. Memberikan sumbangsih pemikiran pihak sekolah untuk terus mengembangkan serta meningkatkan kompetensinya dalam penerapan pendidikan karakter melalui kegiatan gerakan kepanduan hizbul wathan, disinilah timbul konsep dan strategi pembina dalam hal pencapaian hasil pendidikan karakter yang efektif dan efisien.

Kata kunci: Pendidikan, Karakter, Hizbul Wathan

Pada hakekatnya manusia mempunyai potensi fujur dan taqwa. Ketakwaan yang dimiliki manusia, maka akan melahirkan karakter yang baik. Manusia yang mempunyai karakter yang baik, apabila diberi amanah menjadi pemimpin sebuah negara, maka negara tersebut akan dikelola menjadi negara yang adil dan makmur. Sebaliknya, jika manusia mempunyai karakter buruk, maka tunggulah kehancuran. Menyadari begitu pentingnya karakter bangsa yang harus dimiliki manusia, para founding father (bapak pendiri bangsa) menyebutkan paling tidak ada tiga tantangan besar yang harus dihadapi. Pertama,mendirikan negara yang bersatu dan berdaulat. Kedua, membangun bangsa.Ketiga, pembangunan karakter bangsa (nation and character building) (Hariyanto, 2013: 1).

Pendidikan tidak hanya mendidik para peserta didik menjadikan manusia yang cerdas, tetapi juga membangun kepribadiannya agar berakhlak mulia. Saat ini, pendidikan di Indonesia dinilai oleh banyak kalangan tidak bermasalah dengan peran pendidikan dalam mencerdaskan para peserta didiknya, namun dinilai kurang berhasil dalam membangun kepribadian peserta didiknya agar berakhlak mulia. Oleh karena itu, pendidikan akhlak sebagai kebutuhan yang mendesak.
Ketiga tantangan tersebut dalam pelaksanaannya membutuhkan kerjasama semua komponen, baik pemerintah maupun setiap warga negara. Dari ketiga hal tersebut yang sekarang menjadi sorotan publik adalah membangun karakter bangsa.

Alasan perlunya membangun karakter bangsa yakni keberadaan karakter dalam bangsa merupakan pondasi. Bangsa yang memiliki karakter kuat, mampu menjadikan dirinya sebagai bangsa yang bermartabat dan disegani oleh bangsa-bangsa lain. Pesan mantan Mendiknas Bapak Mohammad Nuh: Karakter pribadi seseorang, sebagian besar dibentuk oleh pendidikannya. Karena itu, untuk membentuk pribadi yang terpuji, tanpa cela, dan bertanggungjawab, mutlak dibutuhkan pendidikan yang berkualitas pendidikan karakter.

Pembentukan karakter merupakan salah satu tujuan pendidikan nasional. Pasal 3 UndangUndang Nomor 20 Tahun 2003 tentang Sistem Pendidikan Nasional (Sisdiknas) menyatakan tujuan pendidikan nasional adalah mengembangkan potensi peserta didik agar menjadi manusia yang beriman dan bertaqwa kepada Tuhan Yang Maha Esa, berakhlak mulia, sehat, berilmu, cakap, kreatif, mandiri, dan menjadi warga negara yang demokratis serta bertanggung jawab. Amanah UU Sisdiknas tahun 2003 itu bermaksud agar pendidikan tidak hanya membentuk insan Indonesia yang cerdas, namun juga berkepribadian atau berkarakter, sehingga nantinya akan lahir generasi bangsa yang tumbuh berkembang dengan karakter yang bernafaskan nilai luhur bangsa, agama dan budaya.

Menurut Kesuma, kondisi moral/moral generasi muda mulai rusak/hancur. Hal ini ditandai dengan maraknya seks bebas dikalangan remaja (generasi muda), peredaran narkoba dikalangan remaja, tawuran pelajar, peredaran foto dan vidio porno pada kalangan pelajar, dan sebagainya (Johar, 2012: 2).

Selanjutnya menurut Kesuma, data hasil survey mengenai seks bebas dikalangan remaja Indonesia menunjukkan $63 \%$ remaja Indonesia melakukan seks bebas, sedangkan remaja korban narkoba di Indonesia ada 1,1 juta orang atau 3,9\% dari jumlah total korban (Johar, 2012: 2).

Pendidikan karakter merupakan upaya untuk membantu perkembangan jiwa anak-anak 


\section{Hagil Penelition}

baik lahir maupun batin, dari sifat kodratinya menuju ke arah peradaban yang manusiawi dan lebih baik. Sebagai contoh dapat dikemukakan misalnya: anjuran atau suruhan terhadap anak-anak untuk duduk yang baik, tidak berteriak-teriak agar tidak mengganggu orang lain, bersih badan, rapi pakaian, hormat terhadap orang tua, menyayangi yang muda, menghormati yang tua, menolong teman, dan seterusnya merupakan proses pendidikan karakter.

Sumber utama penentuan karakter dalam Islam, adalah al-Quran dan hadis Nabi Muhammad saw. Ukuran baik dan buruk dalam karakter Islam berpedoman pada kedua sumber ini, bukan menurut ukuran manusia. Sebab jika ukurannya adalah manusia, baik dan buruk akan berbeda-beda. Kedua sumber pokok tersebut (al-Quran dan sunnah) diakui oleh semua umat Islam sebagai dalil naqli yang tidak diragukan otoritasnya. Melalui kedua sumber inilah dapat dipahami dan diyakini bahwa sifat-sifat sabar, qana'ah, tawakkal, syukur, pemaaf, dan pemurah termasuk sifat-sifat yang baik dan mulia. Sebaliknya, dapat dipahami pula bahwa sifat-sifat syirik, kufur, nifaq, ujub, takabur, dan hasad merupakan sifat-sifat tercela. Islam tidak mengabaikan adanya standar lain selain al-Quran dan sunnah/hadis untuk menentukan baik dan buruk dalam hal karakter manusia. Standar lain dimaksud adalah akal dan nurani manusia serta pandangan umum (tradisi) masyarakat.

Pendidikan karakter harus dibangun mulai sedini mungkin, mulai dari keluarga, sekolahan, hingga masyarakat. Sekolah termasuk lembaga yang ikut menentukan pendidikan dari seorang siswa. Menurut Zubaedi, bahwa sekolah berpengaruh sangat besar terhadap perkembangan kepribadian anak, baik dalam berfikir, bersikap, maupun berperilaku karena sekolah merupakan substansi dari keluarga dan guru sebagai substansi orang tua. Begitu juga dengan arah dan kebijakan prioritas pendidikan karakter ditegaskan bahwa pendidikan sudah menjadi bagian yang terpisahkan dengan visi pembangunan nasional jangka panjang 2005-2025 (Zubaedi, 2012: 7).

Penanaman dan pengembangan pendidikan karakter pada siswa dapat dilakukan dalam pendidikan formal maupun non formal. Pendidikan karakter dalam pendidikan non formal dilakukan di lingkungan keluarga dan masyarakat, sedangkan dalam pendidikan formal dapat dilakukan di sekolah salah satunya dengan cara mengikuti kegiatan Hisbul Wathan (HW), semua itu dimaksudkan untuk dapat menciptakan generasi muda yang sadar sebagai warga negara yang baik, menghasilkan perubahan perilaku yang lebih matang secara psikologi dan sosio-kultural, khususnya sebagai warga negara yang sadar hak dan kewajibannya.

Berdasarkan uraian diatas, maka dalam tulisan ini akan dibahas: pertama, bagaimana penerapan pendidikan karakter melalui gerakan kepanduan hizbul wathan di Sekolah Dasar Muhammadiyah 6 Kota Palembang; kedua, apakah faktor-faktor yang menghambat penerapan pendidikan karakter melalui gerakan kepanduan hizbul wathan di Sekolah Dasar Muhammadiyah 6 Kota Palembang.

\section{Konsep Pendidikan Karakter}

Sebagai bangsa Indonesia setiap dorongan harus berlandaskan Pancasila. Karakter yang berlandaskan falsafah Pancasila maknanya adalah setiap aspek karakter harus dijiwai oleh kelima sila pancasila secara utuh dan komprehensif sebagai berikut (Hariyanto, 2012: 22-25): 1) Bangsa yang ber-ketuhanan Yang Maha Esa; 2) Bangsa yang menjunjung kemanusiaan yang adil dan beradab; 3) Bangsa yang mengedepankan persatuan dan kesatuan bangsa; 4) Bangsa yang demokratis dan menjunjung tinggi hukum dan HAM; 5) Bangsa yang mengedepankan keadilan dan kesejahteraan.

Secara sederhana pendidikan dapat dimaknai sebagai usaha untuk membantu peserta didik mengembangkan seluruh potensinya (hati, fikiran, rasa, dan karsa, serta raga) untuk menghadapi masa depan (Hariyanto, 2012: 37). Menurut Triling dan Fadel ada tiga kategori ketrampilan yang diperlukan pada abad ini, Pertama kecakapan belajar dan inovasi yang meliputi: berfikir kritis dan pemecahan masalah, komunikasi dan kolaborasi, serta kreativitas dan inovasi. Kedua kecakapan melek digital yang meliputi: melek media, dan melek teknologi informasi dan komunikasi. Ketiga kecakapan hidup dan kecakapan karier yang meliputi: keluwesan dan penyesuaian diri, inisiatif dan arahan diri, interaksi sosial dan interaksi lintas budaya, produktivitas, 


\section{Haril Penelitian}

dan akuntabilitas, kepemimpinan dan tanggung jawab (Hariyanto, 2012: 37-38).

\section{Pengertian Pendidikan Karakter}

Pendidikan karakter adalah sebuah proses transpormasi nilai-nilai kehidupan untuk ditumbuhkembangkan dalam kepribadian seseorang sehingga menjadi satu dalam kehidupan orang itu. Dalam definisi tersebut, ada tiga pikiran penting, yaitu proses transpormasi, ditumbuhkembangkan dalam kepribadian, dan menjadi salah satu dalam prilaku (Johar P, 2012: 5).

Locword mendefinisikan pendidikan karakter sebagai aktivitas berbasis sekolah yang mengungkap secara sistematis bentuk prilaku dari siswa (Hariyanto, 2013: 45). Dari definisi Locword tersebut, ternyata pendidikan karakter dihubungkan dengan setiap rencana sekolah, yang dirancang bersama lembaga masyarakat yang lain, untuk membentuk secara lansung dan sistematis perilaku orang muda. Dengan demikian, idealnya pelaksanaan pendidikan karakter merupakan yang terintegrasi dengan program kegiatan disebuah sekolah.

Menurut Lickona pendidikan karakter akan meningkatkan kognitif, afektif, dan prilaku manusia yang lebih bermoral (Thomas, 2013: 69). Pendidikan karakter yang baik, ideal disebut sebagai pendidikan karakter luhur. Konsep ini mencakup makna etik dan etiket sekaligus. Artinya, pendidikan karakter adalah nilai, aturan baik buruk yang harus diaplikasikan dalam kehidupan seharihari. Dalam konsep spiritualisme Islam makna ini sejajar dengan konsep akhlaqul karimah (akhlak mulia). Pengajaran dan penanaman pendidikan karakter luhur sangat penting dalam perkembangan kehidupan manusia, apalagi untuk anak-anak.

Pendidikan karakter merupakan pendidikan yang terintegrasi dengan pembelajaran yang terjadi pada semua mata pelajaran. Pendidikan karakter diarahkan pada pengembangan perilaku anak secara utuh. Asumsinya anak merupakan organisme manusia yang memiliki potensi untuk dikuatkan dan dikembangkan. Penguatan dan pengembangan perilaku dalam pendidikan karakter didasari oleh nilai yang dirujuk sekolah.

\section{Fungsi dan Tujuan Pendidikan Karakter}

Sebagaimana dalam Pasal 3 UU Sistem

Pendidikan Nasional Nomor 20 Tahun 2003, bahwa pendidikan nasional bertujuan mengembangkan dan membentuk watak serta peradaban bangsa yang bermartabat dalam rangka mencerdaskan kehidupan bangsa. Adapun tujuannya adalah untuk mengembangkan potensi peserta didik agar menjadi manusia yang beriman bertakwa kepada Tuhan Yang Maha Esa, berakhlak mulia, sehat, berilmu, cakap, kreatif, mandiri, dan menjadi warga negara yang demokratis serta bertanggung jawab.

Sebagaimana dalam UU No. 20 Tahun 2003 tentang Sistem Pendidikan Nasional pasal 3 dijelaskan bahwa pendidikan nasional berfungsi mengembangkan kemampuan dan membentuk watak serta peradaban bangsa yang bermartabat dalam rangka mencerdaskan kehidupan bangsa, bertujuan untuk berkembangnya potensi peserta didik agar menjadi manusia yang beriman dan bertakwa kepada Tuhan Yang Maha Esa, berakhlak mulia, sehat, berilmu, cakap, kreatif, mandiri, dan menjadi warga negara yang demokratis serta bertanggung jawab. Fungsi dari pendidikan nasional tersebut merupakan fungsi dari pelaksanaan pendidikan karakter yang pada intinya adalah mencetak generasi bangsa yang tidak hanya berilmu tetapi juga memiliki akhlak mulia.

\section{Prinsip Pendidikan Karakter}

Penyelenggaraan pendidikan karakter di sekolah harus mengacu pada prinsip- prinsip yang mampu menjadikan penyelenggaraan pendidikan karakter mudah dimengerti dan dilaksanakan oleh semua pihak yang berkecimpung dalam penyelenggaraannya. Adapun prinsip-prinsip yang digunakan dalam pengembangan pendidikan karakter tersebut adalah: 1) Berkelanjutan, penanaman karakter bukan seperti halnya membalik telapak tangan, akan tetapi untuk membentuk kerakter anak diperlukan waktu yang panjang dan harus diselenggarakan secara berkelanjutan dalam tiap jenjang pendidikan. Sejak dini anak harus ditanamkan karakter-karakter yang baik dan dikembangkan sampai terinternalisasi dalam dirinya dan mampu mengaplikasikannnya dalam kehidupan sehari-hari. Oleh sebab itu, pendidikan karakter harus diselenggarakan sejak pendidikan dasar dan tidak hanya diselenggarakan di sekolah, akan tetapi juga berkelanjutan di rumah; 2) Melalui semua mata pelajaran, pengembangan diri, dan budaya sekolah. Penyelenggaraan pendidikan karakter 


\section{Hagil Penelition}

bukan kewajiban salah satu mata pelajaran, akan tetapi semua mata pelajaran dan kegiatan kuriluker dan ekstrakulikuler yang diikuti peserta didik harus memiliki ruh penanaman karakter dan kewajiban semua guru mata. Selain itu, pendidikan karakter bukan hanya sebuah teori dalam kelas. Akan tetapi sebuah pembiasaan melalui budaya- budaya yang harus dikembangkan disetiap lingkungan; 3) Nilai tidak diajarkan tapi dikembangkan;mengandung makna bahwa materi nilai karakter bukanlah bahan ajar biasa; artinya, nilai-nilai itu tidak dijadikan pokok bahasan yang dikemukakan seperti halnya ketika mengajarkan suatu konsep, teori, prosedur, ataupun fakta seperti dalam mata pelajaran agama, bahasa Indonesia, PKn, IPA, IPS, matematika, pendidikan jasmani dan kesehatan, seni, dan ketrampilan; dan 4) Proses pendidikan dilakukan peserta didik secara aktif dan menyenangkan; prinsip ini menyatakan bahwa proses pendidikan nilai karakter bangsa dilakukan oleh peserta didik bukan oleh guru. Guru menerapkanprinsip "tut wuri handayani" dalam setiap perilaku yang ditunjukkan pesertadidik. Prinsip ini juga menyatakan bahwa proses pendidikan dilakukan dalam suasana belajar yang menimbulkan rasa senang dan tidak indoktrinatif.

Selain keempat prinsip tersebut, Thomas Lickona dalam bukunya menjelaskan bahwa beberapa prinsip yang dapat menghantarkan kesuksesan penyelenggaraan pendidikan karakter di sekolah diantaranya yaitu: 1) Pendidikan karakter harus mengandung nilai-nilai yang dapat membentuk good character; 2) Karakter harus didefinisikan secara menyeluruh untuk mencakup aspek pemikiran, perasaan dan perilaku; 3) Pendidikan karakter yang efektif memerlukan pendekatan komprehensif dan terfokus pada semua aspek yang ada di sekolah; 4) Lingkungan sekolah harus menjadi miniatur masyarakat yang damai dan harmonis serta peduli; 5) Untuk mengembangkan nilai-nilai karakter diperlukan kesempatan; 6) untuk mempraktekkan dan membiasakan nilai-nilai tersebut dalam kehidupan sehari-hari; 7) Pendidikan karakter yang efektif harus mengikutsertakan materi kurikulum yang berarti bagi kehidupan anak, yang berbasis kompetensi atau life skill; 8) Pendidikan karakter harus mampu mengembangkan motivasi internal peserta didik; 9) Seluruh staf sekolah harus terlibat dalam penyelenggaraan pendidikan karakter dan menjadi model bagi peserta didik dalam menerapkan nilainilai; 10) Pendidikan karakter di sekolah memerlukan kepemimpinan moral dari berbagai pihak; dan 11) Penyelenggaraan pendidikan karakter harus melibatkan orang tua, dan masyarakat sekitar.

Dalam penyelenggaraan pendidikan karakter harus ada evaluasi berkala untuk mengukur keberhasilan pendidikan karakter. Sekolah harus memiliki standar keberhasilan dalam penyelenggaraan pendidikan karakter, khususnya standar yang mencakup aspek bagaimana perkembangan karakter peserta didik, guru dan stafstaf lainnya yang berada di lingkungan sekolah.

\section{Tahap Pendidikan Karakter}

Pendidikan karakter dibagi menjadi beberapa tahapan, yaitu: tahapan adab, tahapan tanggung jawab, tahapan caring, tahapan kemandirian, dan tahapan bermasyarakat (Furqon, $\mathrm{tt}:$ 32).

Tahapan Adab (Usia 5- 6 tahun). Pada usia 5- 6 tahun, anak dididik untuk mengenal nilai-nilai benar dan salah, atau karakter baik dan buruk. Anak diajarkan untuk mulai mengetahui mana yang harus dilakukan dan mana yang harus ditinggalkan. Anak dikenalkan dengan Tuhannya melalui agama yang dianut, diajak menirukan gerakan ibadah, dan mambiasakan berperilaku sopan. Pada usian ini, anak telah memasuki pendidikan formal pada jenjang pendidikan pra sekolah atau Taman KanakKanak.

Tahapan tanggung jawab ( Usia 7- 8 tahun). Dalam sebuah hadits yang dijelaskan bahwa, anak pada usia 7 tahun untuk dianjurkan mulai melaksanakan ibadah yang diperintahkan. Hal ini menandakan bahwa pada usia 7 tahun, anak harus dibiasakan mulai memiliki tanggung jawab untuk melaksanakan kewajibannya, memenuhi kebutuhannya sendiri, seperti mandi, makan, berpakaian dilakukan dengan sendirinya. Usia 7 tahun, anak telah memasuki jenjang pendidikan dasar.

Tahapan Caring -peduli (9-10 tahun). Jika pada usia 7 tahun anak sudah mengenal tanggung jawab dan kepeduliannya terhadap dirinya sendiri, maka pada usia 9-10 tahun, anak harus mulai diajarkan untuk memiliki kepedulian terhadap 


\section{Hasil Penelitian}

orang lain yang ada di sekitarnya. Menghormati hak- hak dan kewajiban orang lain, dan tolongmenolong sesama. Adanya rasa kepedulian terhadap orang lain, akan menumbuhkan jiwa- jiwa kepemimpinan pada anak.

Tahapan kemandirian ( Usia 11-12 tahun). Pendidikan karakter yang telah didapat anak pada usia sebelumnya akan menjadikan anak lebih desawa, mematangkan karakter anak sehingga menimbulkan sikap kemandirian pada anak. Kemandirian ini akan ditandai adanya sikap mau menerima segala resiko dari perbuatan yang dilakukan, mulai mampu membedakan mana yang baik dan yang benar.

Tahapan bermasyarakat ( Usia 13 tahun keatas). Pada tahapan ini, anak dipandang telah mampu hidup bergaul dalam masyarakat luas. Anak mulai diajarkan untuk memiliki sikap integritas dan kemampuan beradabtasi dengan berbagai jenis lapisan masyarakat. Pengalaman-pengalaman yang didapatkan dalam tahapan sebelumnya diharapkan mampu mewarnai kehidupan bermasyarakatnya, dan karakter-karakter yang telah ditanamkan pada tahapan sebelumnya juga diharapkan mampu diimplementasikan dalam kehidupan bermasyarakat.

\section{Nilai-Nilai dalam Pendidikan Karakter}

Pendidikan karakter berpijak dari karakter dasar manusia, yang bersumber dari nilai moral universal (bersifat absolut) yang bersumber dari agama yang juga disebut sebagai the golden rule. Pendidikan karakter dapat memiliki tujuan yang pasti, apabila berpijak dari nilai-nilai karakter dasar tersebut.

Menurut para ahli psikolog, beberapa nilai karakter dasar tersebut adalah: cinta kepada Allah dan ciptaan-Nya (alam dengan isinya), tanggung jawab, jujur, hormat dan santun, kasih sayang, peduli, dan kerjasama, percaya diri, kreatif, kerja keras, dan pantang menyerah, keadilan dan kepemimpinan; baik dan rendah hati, toleransi, cinta damai, dan cinta persatuan.

Pendidikan karakter dianggap sebagai pendidikan nilai moralitas manusia yang disadari dan dilakukan dalam tindakan nyata. Tampak di sini terdapat unsur pembentukan nilai tersebut dan sikap yang didasari pada pengetahuan untuk melakukannya. Nilai-nilai itu merupakan nilai yang dapat membantu interaksi bersama orang lain secara lebih baik (learning to live together). Nilai tersebut mencakup berbagai bidang kehidupan, seperti hubungan dengan sesama (orang lain, keluarga), diri sendiri (learning to be), hidup bernegara, lingkungan dan Tuhan.

\section{Perbedaan Pendidikan Akhlak dan Pendidikan Karakter}

Pendidikan Akhlak, mengenai penjelasan akhlak secara luas, banyak sekali tokoh yang memberikan pengertian secara bervariasi. Diantaranya M. Abdullah Darraz, menurut beliau akhlak adalah sesuatu kekuatan dalam kehendak yang mantap, kekuatan dan kehendak mana berkombinasi membawa kecenderungan pada pemilihan pihak yang benar (akhlak yang baik) atau pihak yang jahat (akhlak yang jahat) (Erwin, 2009: 182).

Tujuan puncak pendidikan akhlak adalah terbentuknya karakter positif dalam perilaku anak didik. Karakter positif ini tiada lain adalah penjelmaan sifat-sifat mulia Tuhan dalam kehidupan manusia.

Pendidikan karakter yang berbasis Al Qur'an dan Assunnah, gabungan antara keduanya yaitu menanamkan karakter tertentu sekaligus memberi benih agar peserta didik mampu menumbuhkan karakter khasnya pada saat menjalani kehidupannya. Hanya menjalani sejumlah gagasan atau model karakter saja tidak akan membuat peserta didik menjadi manusia kreatif yang tahu bagaimana menghadapi perubahan zaman, sebaliknya membiarkan sedari awal agar peserta didik mengembangkan nilai pada dirinya tidak akan berhasil mengingat peserta didik tidak sedari awal menyadari kebaikan dirinya. Melalui gabungan dua paradigma ini, pendidikan karakter akan bisa terlihat dan berhasil bila kemudian seorang peserta didik tidak akan hanya memahami pendidikan nilai sebagai sebuah bentuk pengetahuan, namun juga menjadikannya sebagai bagian dari hidup dan secara sadar hidup berdasar pada nilai tersebut.

\section{Kegiatan Ekstra Kurikuler Gerakan Kepanduan Hizbul Wathan}

Istilah ekstrakulikuler secara etimologi terdiri dari "ekstra" dan "kulikuler". Ekstra artinya 


\section{Hagil Penelition}

tambahan diluar yang seharusnya dikerjakan. Sedangkan kulikuler berkaitan dengan kurikulum, yaitu perangkat mata pelajaran yang diajarkan pada suatu lembaga tertentu. Akan tetapi mengingat pengertian kurikulum mengalami banyak perkembanganm maka kurikulum tidak lagi hanya sekedar jumlah mata pelajaran yang harus dialui melaikan program yang disiapkan suatu lembaga pendidikan untuk mencapai tujuan tertentu. Program itu berisi rumusan rencana dan pengaturan mengenai tujuan, isi bahan pelajaran, dan cara yang digunakan sebagai pedoman penyelenggaraan kegiatan pembelajaran untuk mencapai tujuan pendidikan tetentu.

Pendidikan di sekolah secara umum menyenggarakan 2 kegiatan, yaitu kegiatan intrakurikuler dan ekstrakurikuler. Kegiatan ekstrakurikuler adalah kegiatan pendidikan di luar mata pelajaran yang sudah terstruktur dan terjadwal. Sedangkan pendidikan melalui mata pelajaran yang terstruktur dan terjadwal sesuai dengan standar isi, termasuk kegiatan intrakurikuler. Adapaun kegiatan ekstrakurikuler di sekolah adalah kegiatan pembelajaran yang dilakukan diluar jam pembelajaran intrakurikuler, yang dilaksanakan di sekolah atau di luar sekolah untuk lebih memperluas pengetahuan, wawasan, kemampuan, meningkatkan dan menerapkan nilai pengetahuan dan kemampuan yang telah dipelajari dalam kegiatan intrakurikuler yang dituangkan dalam standar kopetensi kelompok mata pelajaran.

Dalam panduan pengembangan diri yang diterbitkan oleh Departemen Pendidikan Nasional, ekstrakurikuler adalah kegiatan pendidikan di luar mata pelajaran untuk membatu pengembangan peserta didik sesuai dengan kebutuhan, potensi, bakat dan minat.

Pengertian ekstrakurikuler yang terdapat pada Peraturan Menteri Agama No 16 Tahun 2010 bahwa kegiatan ekstrakurikuler adalah upaya pemantapan dan pengayaan nilai-nilai dan norma serta pengembangan kepribadian, bakat dan minat peserta didik pendidikan agama yang dilaksanakan di luar jam intrakurikuler dalam bentuk tatap muka atau non tatap muka.

\section{Pengertian Gerakan Kepanduan Hizbul Wathan}

Hizbul Wathan adalah gerakan kepanduan Muhammadiyah yang dibentuk oleh KH. Ahmad
Dahlan pada 1918 (Hidayatullah, 2002: 398). Hizbul Wathan adalah lembaga kepanduan yang didirikan oleh beberapa orang tokoh Muhammadiyah dalam rangka pembinaan terhadap kader - kader mudanya (Yunan, 2005: 401).

Hizbul Wathan adalah sebuah organisasi otonom Muhammadiyah yang bergerak dibidang kepanduan untuk menyiapkan dan membina anak, remaja, dan pemuda yang memiliki aqidah, mental dan fisik, berilmu dan berteknologi serta berakhlaq karimah dengan tujuan untuk terwujudnya pribadi muslim yang sebenar-benarnya dan siap menjadi kader persyarikatan, umat, dan bangsa dengan metode yang menarik, menantang dan menyenangkan (Dzikron, 2014: 34). Muhammadiyah organisasi Islam beraliran maju. Muhammadiyah sejak berdirinya maju pesat, jumlah anggotanya naik cepat. Berhasil mendirikan banyak rumah sekolah, memberikan kursus-kursus agama, mendirikan poliklinik-poliklinik, perumahan anak yatim-piatu, dll. Pengajaran modern untuk anak-anak perempuan sangat diperhatikan. Bagian wanitanya Aisyiyah, berdiri sendiri. Gerakan pemudanya ialah Kepanduan Hizbul Wathan.( Kanisius, 1984: 720).

Jadi yang dimaksud implementasi kegiatan ekstrakurikuler Hizbul Wathan adalah penerapan kegiatan tambahan yang dilaksanakan di luar mata pelajaran dengan sistem kepanduan Islam dan menggunakan metode kepanduan yang didirikan oleh organisasi Muhammadiyah yang tugas utamanya mendidik anak, remaja, dan pemuda agar terwujudnya pribadi muslim.

\section{Visi Gerakan Kepanduan Hizbul Wathan}

Pandu Hizbul Wathan adalah kader-kader Muhammadiyah yang berpandangan luas dan jauh ke depan yang senantiasa siap mengawal, mengembangkan dan meneruskan perjuangan Muhammadiyah untuk melaksanakan dakwah amar ma"ruf dan nahi munkar guna mewujudkan masyarakat uatam yang diridhai Allah SWT. Misinya mendidik putra putri Muhammadiyah menjadi kader-kader agama, umat dan bangsa.

\section{Maksud dan Tujuan Gerakan Kepanduan Hizbul Wathan}

Membahas mengenai maksud dan tujuan Kepanduan Hizbul Wathan tentunya kita tidak bisa 


\section{Hasil Penelitian}

lepas dari Anggaran Dasar Kepanduan Hizbul Wathan sebagai bahan acuan penyelenggaraan kegiatan kepanduan ini. Maksud dan tujuan Kepanduan Hizbul Wathan adalah: Adapun tujuan dari kegiatan ekstrakurikuler sebagai berikut: 1) Meningkatkan kompetensi peserta didik dalam aspek kognitif, afektif, dan psikomotorik; 2) Mengembangkan bakat dan minat peserta didik dalam uapaya pembinaan pribadi menuju pembinaan manusia seutuhnya yang positif; 3) Memacu kemampuan mandiri, percaya diri, dan kreativitas peserta didik; 4) Untuk memperdalam dan memperluas pengetahuan peserta didik; 5) Meningkatkan kualitas keimanan dan ketakwaan kepada Tuhan Yang Maha Esa; 6) Meningkatkan kesadaran berbangsa dan bernegara; dan 7) Membina budi pekerti yang luhur

Maksud Hizbul Wathan adalah menyiapkan dan membina anak, remaja, dan pemuda yang memiliki aqidah, mental dan fisik, berilmu dan berteknologi serta berakhlaq karimah dengan tujuan untuk terwujudnya pribadi muslim yang sebenar-benarnya dan siap menjadi kader persyarikatan, umat, dan bangsa.

Tujuan gerakan kepanduan hizbul wathan adalah menyiapkan dan membina anak, remaja, dan pemuda yang memiliki aqidah, mental dan fisik, berilmu dan berteknologi serta berakhlak karimah terwujudnya pribadi muslim yang sebenar-benarnya dan siap menjadi kader persyerikatan, umat dan bangsa.

Sedangkan tujuan pembinaan pandu melalui kegiatan adalah: 1) Terwujudnya manusia Indonesia yang berkpribadian baik atau memiliki akhlak mulia; 2) Mendidik kader-kader bangsa menjadi pemimpin yang bertanggung jawab dan dapat dipercaya; 3) Memiliki disiplin yang tinggi dalam melaksanakan semua kegiatan; 4) Memiliki moral sesuai dengan norma agama Islam; 5) Memiliki kemampuan untuk berkomunikasi dengan masyarakat di sekitar lingkungannya atau orang lain; 6) Tabah dan tangguh dalam menghadapi semua tantangan; 7) Berguna bagi masyarakat di sekitar lingkungannya atau orang lain; 8) Mampu menggunakan waktu secara efisien dalam segala hal; 9) Mengembangkan sikap kerja dengan masyarakat atau teman; dan 10) Bersikap ramah kepada sesama.
Penerapan Kegiatan Hizbul Wathan dalam Membentuk karakter Siswa di Sekolah Dasar Muhammadiyah 6 Palembang

Kehadiran kepanduan Hizbul wathan dalam organisasi adalah untuk melaksanakan kegiatan agar suatu tujuan dapat tercapai dengan efektif dan efisien. Kegiatan proses pencapaian tujuan tersebut yaitu berupa tindakan-tindakan yang mengacu kepada fungsi gerakan kepanduan hizbul wathan.

Peran guru pembina gerakan hizbul wathan sangat dibutuhkan dalam penerapanmembentuk karakter peserta didik dikarenakan didalamnya guru dituntut untuk memberikan keteladanan kepada peserta didik agar memiliki karakter, diri sendiri, sesama dan lingkungan sehingga diharapkan bisa menjadi insan kamil. Berikut yang diimplementasikan guru pembina kepanduan hizbul wathan di Sekolah Dasar Muhammadiyah 6 kota Palembang membentuk karakter peserta didik.

Sekolah Dasar Muhammadiyah 6 kota Palembang sebagai lembaga pendidikan dengan konsep peranan pendidikan karakter secara aktif menyusun program Kegiatan Hizbul Wathan secara bersama-sama antara kepala sekolah, dewan guru dan wakil kepala sekolah. Hal ini sesuai dengan rangkuman hasil wawancara dengan kepala sekolah Muhammadiyah 6 kota Palembang Humaro, S.Pd. sebagai berikut:

"Visi adalah wawasan yang menjadi sumber arahan bagi sekolah dan dapat digunakan untuk meniti rumusan misi sekolah. Setiap sekolah harus memiliki visi, karena visi merupakan gambaran masa depan yang dii 82 oleh sekolah,agar sekolah yang bersan 82 lapat menjamin kelangsungan hidup dan perkembangannya. Adapun visi di SD Muhammadiyah 6 adalah sebagai berikut: "Dengan iman yang kokoh serta berwawasan ISMUBA membentuk siswa yang cerdas, terampil dan mandiri".

Misi adalah bentuk layanan untuk memenuhi tuntutan yang dituangkan dalam visi dengan berbagai indikatornya. Adapaun misi Sekolah Dasar Muhammadiyah 6 Palembang adalah: 1) Membentuk kemandirian akhlak siswa berdasarkan Al qur'an dan Hadist; 2) Menumbuhkan kedisiplinan Sekolah dan membaca Al qur'an; 3) Melaksanakan pembelajaran dan 


\section{Haril Penelitian}

bimbingan siswa sesuai potensi masing-masing secara efektif; 4) Meningkatkan semangat kekeluargaan antara pihak sekolah, wali murid dan masyarakat lingkungan sekolah; dan 5) Disiplin Waktu

Tujuannya adalah Membentuk manusia muslim yang beriman bertaqwa, beraklak mulia, cakap percaya diri sendiri, berdisiplin tanggung jawab, cinta tanah air memajukan memperkembangkan ilmu pengetahuan dan terampil dan beramal menuju terwujudnya masyarakat Islam yang sebenar benarnya" (Wawancara dengan Humaro)Didalam melaksanakan fungsi kepanduan gerakan hizbul wathan dalam hal ini perencanaan akan tampak pada indikator-indikator perencanaan didalam program kegiatan hizbul wathan yang dilaksanakan. Adapun hal-hal yang direncanakan kepala sekolah Muhammadiyah 6 kota Palembangdalam membentuk karakter peserta didik adalah membangun kedisiplinan, salah satu cara yang dilakukan adalah mengadakan ataupun mengembangkan kegiatan hizbul wathan dengan memperhatikan sumber daya sekolah.

$$
\text { "Saya selaku kepala sekolah }
$$

Muhammadiyah 6 kota Palembangdalam menyusun Rencana Kegiatan dan Anggaran Sekolah (RKAS) di setiap tahun ajaran barunya bersama dewan guru dan orangtua melalui rapat/musyawarah awal tahun dan dengan memperhatikan sumber daya manusia, keuangan, sarana dan prasarana. Untuk membentuk karakter peserta didik, maka Muhammadiyah 6 kota Palembanglebih mengintensifkan dan mengembangkan kegiatan hizbul wathan" (Wawancara dengan Humaro)

Dalam buku Etika Pendidikan Karangan Prof. Abdullah Idi, menjelaskan bahwa karakter merupakan kualitas moral dan mental yang pembentukanya dipengaruhi oleh faktor bawaan (fitrah atau nature) dan lingkungan (sosialisasi atau lingkungan, nurture). Potensi karakter yang baik dimiliki seseorang sebelum dilahirkan harus terusmenerus dikembangkan melalui sosialisasi dan pendidikan (Abdullah, 2015: 124).

Dengan demikian setiap individu mempunyai karakteristik bawaan dan karakteristik yang dipengaruhi oleh lingkungan. Karakteristik bawaan merupakan karakteristik keturunan yang dibawa sejak ia lahir baik yang berhubungan dengan faktor biologis maupun sosial psikologis. Keyakinan masa lalu mengatakan bahwa kepribadian terbawa pembawaan dan lingkungan; merupakan dua faktor yang terbentuk karena dua faktor yang terpisah, masing-masing mempengaruhi kepribadian dan kemampuan individu bawaan dan lingkungan dengan caranya masing-masing. Namun setelah disadari bahwa apa yang dipikirkan dan dikerjakan oleh seseorang atau apa yang dirasakan oleh siapapun merupakan hasil dari perpaduan dari apa yang ada di antara faktor-faktor biologis yang diturunkan dan pengaruh lingkungan.

Abdullah Idi, mengungkapkan Antara peran keluarga/orang tua dan pengembangan karakter pribadi anak didik tidak dapat dipisahkan. jika anak tumbuh dari keluarga yang lebih fokus terhdap perkembangan anak, akan tumbuh dari keluarga yang lebih fokus terhdap perkembangan anak, akan menumbuhkan pribadi anak berkarakter yang berdampak posistif terhadap kemajuan bangsa ini (Idi, 2015:124).

Salah satu upaya pengembangan karakter dari faktor eksternal adalah lingkungan pendidikan atau lingkungan sekolah. Hizbul Wathan adalah gerakan kepanduan Islam yang dimiliki oleh Muhammadiyah, dinamakan Hizbul Wathan yang menjadi bagian dari kegiatan pembentukan karakter dari unsur kegiatan ekstrakurikuler.

"Ibu Humaro, S.Pd mengungkapkan: Hizbul wathan adalah kegiatan yang dilakukan di luar jam pelajaran formal di lingkungan sekolah yang tujuannya untuk pengembangan diri siswa. Nah Hizbul Wathan adalah gerakan kepanduan Islam yang dimiliki oleh Muhammadiyah, dinamakan Hizbul Wathan yang artinya pembela tanah air dan Hizbul Wathan salah satu gerakan yang lahir sudah lama.(Wawancara dengan Humaro).

Penerapan kegiatan Hizbul Wathan dalam membentuk karakter siswa di sekolah didasari oleh kebijakan Majelis Pendidikan Dasar dan Menengah Pimpinan Pusat Muhammadiyah yang mencanangkan dalam rangka peningkatan kualitas Pembinaan Organisasi Otonom di Sekolah Muhammadiyah untuk menyiapkan kader-kader Muhammadiyah sebagai kader persyarikatan, kader bangsa maupun kader ummat. Yaitu melalui tiga tahap yakni perencanaan, pelaksanaan dan evaluasi. 


\section{Hasil Penelitian}

\section{Perencanaan}

Latar belakang pelaksanaan

ekstrakurikuler Hizbul Wathan Sekolah Dasar

Muhammadiyah 6 Palembang, bahwa aturan mengenai Kepanduan Hizbul Wathan sudah ada dalam keputusan Majlis Pendidikan Dasar dan Menengah Pimpinan Pusat Muhammadiyah Nomor: 08/KTN/I.4/F/2013 tentang Pembinaan Organisasi Otonom di Lembaga Pendidikan Muhammadiyah Bab II Pasal 3 ayat 2. Tujuan yang ingin dicapai dari pelaksanaan kegiatan Hizbul Wathan ialah untuk mewujudkan visi Sekolah Dasar Muhammadiyah 6 Palembang.

Ibu Humaro, S.Pd mengungkapkan "Yang pasti adalah mewujudkan visi misi Sekolah Muhammadiyah 6 Palembang yaitu terwujudnya insan mulia berkompeten, disiplin dan relegius" Berdasarkan hal tersebut, diadakan perencanaan terhadap kegiatan Hizbul Wathan. Guna menunjang kegiatan maka penyusunan perencanaan program kegiatan Hizbul Wathan di Sekolah DasarMuhammadiyah 6Palembang mutlak diperlukan. Bahwa dalam tahap perencanaan kegiatan Hizbul Wathan di Sekolah Dasar Muhammadiyah 6 Palembang merupakan keputusan program dari pusat, kemudian dari pusat diturunkan ke wilayah, dari program wilayah menjadi program sekolah.

IbuHumaro, S.Pd selaku kepala sekolah menuturkan, "Kalau perencanaan itu kita mengacu pada program pusat, program wilayah, kemudian dari program daerah lalu ke program sekolah." Sebelum pelaksanaan kegiatan Hizbul Wathan di Sekolah Dasar Muhammadiyah 6Palembang, pihak sekolah terlebih dahulu membentuk atau menunjuk salah seorang untuk menjadi pembina Hizbul Wathan. Kemudian pihak sekolah dan pembina Hizbul Wathan menyusun program perencanaan yang meliputi program mingguan dan tahunan. Adapum program mingguan kegiatan Hizbul Wathan meliputi pelatihan rutin 1 minggu sekali.

\section{Pelaksanaan}

Setiap pelaksanaan kegiatan memiliki sebuah tujuan. Dan tujuan dilaksanakannya kegiatan Hizbul Wathan bagi para siswanya yaitu salah satunya untuk membentuk karakter Islami sesuai visi misi Sekolah Dasar Muhammadiyah 6 Palembangadalah insan mulai berkompeten disiplin dan relegius. Kegiatan Hizbul Wathan di Sekolah Dasar Muhammadiyah 6 Palembang merupakan salah satu kegiatan yang wajib diikuti oleh semua siswa.

Mengenai pelaksanaan Hizbul Wathan di Sekolah Dasar Muhammadiyah 6 Palembangsecara keseluruhan berjalan lancar. Di lapangannya terdapat 2 guru pembina. Pelaksanaan kegiatan Hizbul Wathan di Sekolah Dasar Muhammadiyah 6 Palembangmerupakan salah satu kegiatan ekstrakurikuler diikuti oleh semua siswa, tetapi pelaksanaannyaterbagi menjadi 4 gelombang yaitu setiap hari Rabu, Jum"at, Sabtu ke-1, dan Sabtu ke2 dari pukul 14.00 sampai 16.00.

Strategi yang digunakan Sekolah Dasar Muhammadiyah 6 Palembang dalam membentuk karakter siswanya terbagi dalam 2 kelompok:

\section{Kegiatan formal}

Melalui KBM dengan cara memasukkan nilai-nilai keagamaan dan nilai-nilai akhlak di dalam setiap mata pelajaran.

Menyisipkan kegiatan-kegiatan di dalam waktu KBM: 1) Kegiatan harian yaitu awal masuk kelas berdoa, menghafalkan doa, tadarus, kuliah tujuh menit, kemudian adzan, sholat berjama"ah; 2) Kegiatan mingguan meliputi sholat jum"at dan kajian Islam; 3) Kegiatan tahunan misalnya pesantren kilat, safari kurban, safari zakat fitrah, kegiatan ramadhan.

\section{Kegiatan nonformal}

Kegiatan yang terpisah dengan KBM yaitu kegiatan LDK 1 dan LDK 2, gladi fisik mental, lomba-lomba dalam rangka milad Muhammadiyah. Bapak Bayumi, S.Ag menjelaskan: di Sekolah Dasar Muhammadiyah 6 Palembangitu memiliki format dalam membentuk karakter itu dibagi dalam 2 kelompok besar yaitu Kegiatan formal dan kegiatan nonformal. Kegiatan formal yaitu melalui KBM, melalui KBM memasukkan nilai-nilai keagamaan dan nilai-nilai karakter di dalam setiap pelajaran. Kemudian yang kedua menyisipkan kegiatan-kegiatan di dalam waktu KBM misalnya yang kita bagi ada kegiatan harian yaitu awal masuk kelas berdoa, menghafalkan doa, tadarus, kuliah tujuh menit, kemudian adzan, sholat berjama"ah. Kemudian yang berikutnya kegiatan mingguan meliputi sholat Jum"at dan kajian Islam. 


\section{Haril Penelitian}

Kemudian kegiatan tahunan misalnya pesantren kilat, safari kurban, safari zakat fitrah, kegiatan ramadhan. Kemudian mengadakan lomba-lomba dalam rangka milad Muhammadiyah, dan dalam rangka acara lain dan itu semua dalam rangka membentuk akhlak siswa (hasil wawancara).

Ibu Humaro, S.Pd mengungkapkan: Kalau ini bukan Hizbul Wathan saja, tapi ini sudah terintegrasi menjadi program pembinaan karakter di sekolah. Yang pertama anak-anak itu berangkat sekolah dengan berpakaian rapi, berjabat tangan dengan guru, masuk kelas lalu berdoa dan membaca al-Qur"an dilanjutkan kultum di kelas, setiap pembelajaran diawali dan ditutup dengan doa, ada pembinaan sholat jumat, dzikir, sholat tarawih, masih banyak kegiatan lain yang tujuannya untuk membentuk akhlak siswa (hasil wawancara).

\section{Evaluasi}

Proses evaluasi yang dilakukan di sini adalah sebagai bentuk tindak lanjut proses pelaksanaan kegiatan Hizbul Wathan. Evaluasi dilakukan sebagai upaya mengukur tingkat keberhasilan suatu program pembelajaran maupun kegiatan yang telah dilaksanakan. Pelaksanaan evaluasi dalam kegiatan Hizbul Wathan di Sekolah Dasar Muhammadiyah 6 Palembangberjalan dengan baik dan lancar.Evaluasi dilaksanakan 2 kali yaitu disetiap akhir semesternya. Ada beberapa aspek yang dinilai dalam kegiatan Hizbul Wathan dalam membentuk akhlak siswanya yaitu hasil penilaian diperoleh dari absensi, pemahaman siswa terhadap materi, praktek, dan dari penilaian terhadap sikap siswa selama mengikuti kegiatan. Kemudian nilai hasil evaluasi dari kegiatan ekstrakurikuler Hizbul Wathan akan dinyatakan dalam raport.

Faktor Pendukung dan Penghambat Kegiatan Hizbul Wathan dalam Membentuk karakter Siswa di Sekolah Dasar Muhammadiyah 6 Palembang

Setiap kegiatan biasanya mempunyai faktor pendukung serta penghambatnya. Pelaksanaan kegiatan Hizbul Wathan yang diselenggarakan di Sekolah Dasar Muhammadiyah 6 Palembangmerupakan salah satu upaya yang dilakukan dalam rangka memberikan fasilitas kepada siswa untuk mengembangkan potensinya.
Hal itu merupakan bukti dukungan yang diberikan dari pihak sekolah demi suksesnya kegiatan tersebut. Selain dukungan moril, pihak sekolahpun selalu memberikan dukungan yang berbentuk materiil demi menunjang kegiatan hizbul wathan.

Pelaksanaan kegiatan Hizbul Wathan di Sekolah Dasar Muhammadiyah 6 Palembang didukung oleh banyak hal, yaitu oleh lembaga persyarikatan dan pihak sekolah. Demi kelancaran Hizbul Wathan di Sekolah Dasar Muhammadiyah 6 Palembang ini pihak sekolah menyediakan sarana dan prasarana yang diperlukan.

Pembina Hizbul Wathan mengatakan: Kalau faktor pendukungnya karena kita berada di lembaga Muhammadiyah, sehingga mudah sekali menyelenggarakan disini dan tidak ada lembagalembaga lain yang menghalangi, untuk pelaksanaannya enak mau diadakan kapan saja, bagaimana caranya, dari pihak sekolah sangat mempersilakan kepada kita, Untuk alat- alat kita termasuk yang lengkap (hasil wawancara).

Selain beberapa faktor pendukung di atas, salah satu faktor pendukung terlaksananya kegiatan Hizbul Wathan adalah adanya dukungan positif dari orang tua siswa. Adanya dukungan orang tua dapat membantu dan memotivasi anak dalam mengikuti setiap kegiatan Hizbul Wathan yangdilaksanakan di Sekolah Dasar Muhammadiyah 6 Palembang.

Meskipun terbilang lancar dalam pelaksanaannya namun tetap saja masih terdapat kekurangan-kekurangan yang menyebabkan tidak maksimalnya kegiatan yang berlangsung. Adapun faktor hambatannya itu faktor intern dari siswa itu sendiri sebagian mereka beranggapan bahwa mereka yang bukan dari persyarikatan Muhammadiyah tidak mau mengikuti Hizbul Wathan dan mereka yang tidak suka dengan kepanduan, mereka akan cenderung untuk membolos atau pura-pura sakit pada pelaksanaan Hizbul Wathan.

Kemudian faktor hambatan yang lain tidak terlepas dari jumlah pembina Hizbul Wathan yang terbatas, sehingga pembina Hizbul Wathan tampak sedikit kesulitan dalam mengondisikan siswa yang jumlahnya banyak. Selanjutnya latihan pelaksanaan Hizbul Wathan terkadang tidak tepat waktu dari yang telah dijadwalkan. Latihan yang harusnya dimulai pukul 14.00 harus mundur beberapa menit karena siswa yang mengikuti Hizbul Wathan datang 


\section{Hasil Penelitian}

terlambat. Namun hal ini tidak mengurangi antusias siswa dalam mengikuti kegiatan.

Selain itu, dalam pelaksanaan kegiatan rutin setiap minggunya sebagian siswa masih terdapat ketidakseriusan dan disiplin siswa dalam mengikuti kegiatan. Dalam hal tersebut pembina Hizbul Wathan juga kurang tegas dalam mengambil sikap. Hal ini menyebabkan kegiatan Hizbul Wathan menjadi tidak kondusif. Hambatanhambatan tersebut tidak dirasakan sebagai sebuah hambatan besar yang dapat mengganggu jalannya kegiatan Hizbul Wathan. Meskipun banyak hambatan dalam kegiatan Hizbul Wathan di Sekolah Dasar Muhammadiyah 6 Palembang, namun kegiatan tersebut tetap berjalan sesuai jadwal yang ditentukan. Agar berjalan lebih maksimal, perlu kerja sama dengan berbagai pihak dalam mengoptimalkan kegiatan Hizbul Wathan baik dari pihak sekolah, siswa maupun orang tua secara intensif.

\section{Kesimpulan}

Penerapan kegiatan Hizbul Wathan dalam membentuk karakter siswa di sekolah didasari oleh kebijakan Majelis Pendidikan Dasar dan Menengah Pimpinan Pusat Muhammadiyah yang mencanangkan dalam rangka peningkatan kualitas Pembinaan Organisasi Otonom di Sekolah Muhammadiyah untuk menyiapkan kader-kader Muhammadiyah sebagai kader persyarikatan, kader bangsa maupun kader ummat. Yaitu melalui tiga tahap yakni perencanaan, pelaksanaan dan evaluasi.

Pelaksanaan kegiatan Hizbul Wathan di Sekolah Dasar Muhammadiyah 6 Palembang didukung oleh banyak hal, yaitu oleh lembaga persyarikatan dan pihak sekolah. Demi kelancaran Hizbul Wathan di Sekolah Dasar Muhammadiyah 6 Palembang ini pihak sekolah menyediakan sarana dan prasarana yang diperlukan. Orang tua siswa juga memberikan dukungan. Adapun faktor hambatannya itu faktor intern dari siswa itu sendiri sebagian mereka beranggapan bahwa mereka yang bukan dari persyarikatan Muhammadiyah tidak mau mengikuti Hizbul Wathan dan mereka yang tidak suka dengan kepanduan, mereka akan cenderung untuk membolos atau pura-pura sakit pada pelaksanaan Hizbul Wathan. Kemudian faktor hambatan yang lain tidak terlepas dari jumlah pembina Hizbul Wathan yang terbatas,

\section{Daftar Pustaka}

Depag. Pedoman Umum Pengelolaan Kesiswaan. Jakarta: direktorat Jenderal Kelembagaan Agama Islam. 2002.

Fakry Gaffar dalam Ratna Megawangi. Pendidikan Karakter Solusi yang Tepat untuk Mebangun Bangsa. Jakarta: BP Migas dan Star Energy. 2010.

Hamid, Hamdani. Pendidikan Karakter Persektif Islam. Bandung: Pustaka Setia. 2003.

Husaini, Usman. Metodelogi Penelitian Sosial. Cet. II. Jakarta: Bumi Aksara. 1996.

Idi, Abdullah, Safarina Hd. Etika Pendidikan. Jakarta: Rajawali Pers. 2015.

Kesuma D, Cepi T, Johar. Pendidikan Karakter:Kajian Teori dan Praktik di sekolah. Bandung: Remaja Rosdakarya. 2012.

Kunandar. Guru Prefesional Implementasi kurikulum Tingkat satuan Pendidikan (KTSP) dan persiapan menghadapi sertifikasi guru. Jakarta: PT Grafindo Persada. 2007.

Kurikulum. Kepanduan Hizbul Wathan tingkat Athfal, Pengenal, Penghela, Penuntun. Departemen diklat Kwartir Pusat Hizbul Wathan. 2014.

Lexy J. Moleong. Metode Penelitian Kualitatif. Bandung: Remaja Rosdakarya. 2005.

Lickona, Thomas. Educating for character: Terjemahan Pendidikan Karakter: Panduan Lengkap Mendidik Siswa Menjadi Pintar dan Baik. New York: Bantam Book. 2013.

Michael Novak dalam Thomas Lickona, Educating for Character Terjemahan endidikan Karakter: Panduan Lengkap Mendidik Siswa Menjadi Pintar dan Baik. New York. Bantam Book.

Mulyasa, E. Manajemen Pendidikan Karakter. Jakarta: Bumi Aksara. 2013.

Nasution. Metode Penelitian Naturalistik Kualitatif . Cet. I;. Bandung: Thersito. 2003.

Nur Zazin. Gerakan Menata Mutu Pendidikan, Jogjakarta: AR-RUZZ MEDIA.2011.

Rusmiyati, dkk. Panduan Mentoring Agama Islam. Jakarta: Iqra Club. 2003.

Robert J. Starmatt. Menghadirkan Pemimpin Visioner. Yogyakarta: KANISIUS. 2007. 


\section{Hasil Penelitian}

Samani, Muchlas dan Hariyanto. 2013. Pendidikan karakter konsep dan model. Bandung: Remaja Rosdakarya. 2013.

Samani M, dan Hariyanto. Konsep dan Model Pendidikan Karakter. Bandung: Remaja Rosdakarya. 2012.
Syafri, Ulil Amri. Pendidikan Karakter Berbasis Al-Qur'an. Jakarta: Raja Grafindo Persada. 2012. 